\title{
GLOBÁLIS VILÁG, NYELVI ÉS KULTURÁLIS HATÁSOK
}

\author{
(Global World, Linguistic and Cultural Effects)
} KONCZOSNÉ SZOMBATHELYI MÁRTA

\begin{abstract}
Kulcsszavak:
nyelvtudás globalizáció interkulturális tapasztalat

Györ a kulföldi tókebefektetések egvik célterülete. Az itt dolgozó menedzserek és alkalmazottak az interkulturális környezet elönyeit és nehézségeit napi munkajuk során is átélik. A szerzō ismerteti az egyik györi, külföldi tulajdonú vállalatnál végzett kutatását, amely négy terïletet érintett: egyrészt a nyelvtudás, nyelvhasználat kérdését; másrészt a vizsgált személyek interkulturális tapasztalatait, felkészältségét; harmadsorban a motiváltságukat a munkában és a nyelvtanulásban; végül a külföldi tulajdonos által közvetített hatást. A tanulmány végén a szerzö következtetéseket von le a nyelvoktatásra, a kultúrák közötti kommunikációra valo felkészültségre, a nyelvek presztízsére, a fejlesztendö területekre vonatkozóan.
\end{abstract}

\section{Bevezetö}

A világméretủ globalizáció - mint a világgazdaság fejlödésének egyik kiemelkedő megatrendje - már sokak által leírt közhely. Mit jelent valójában a szó? Számos érv hozható fel annak bizonyítására, hogy a világgazdaság egységesedési és integrációs folyamatainak már hosszú ideje - sokak szerint évezredek óta - tartó, korábban soha nem látott mértékü felgyorsulása rejlik a globalizáció kifejezéssel jelölt összetett jelenségcsokor mögött. Más megközelítés szerint azonban napjainkban valami egészen új, korábban nem tapasztalt minőség kialakulását éljük át a világ kulturális és gazdasági folyamataiban. Az elmúlt évezredek során mindenekelött a nemzetközi kereskedelem kiterjedésének nyomán került sor a világ kulturális és gazdasági egységesedésére, a világ egyes részei közötti gazdasági és kulturális kapcsolatok bővülésére és elmélyülésére. A legutóbbi száz év során azonban a világgazdaság integrációjának motorjává egyre inkább a külföldi tulajdonszerzés, a tökekivitel vált, s napjaink globalizációs folyamatait is döntỏ mértékben ez mozgatja. Az új típusú globalizáció tehát a tulajdon világméretủ integrálódásán alapul (így pl. a multinacionális vállalatok terjeszkedésén, a tỏke szabad áramlásán, a vállalati koncentráción).

A globalizációnak gazdasági értelemben tehát az az elsódleges jelentése, hogy a termelési egységek tulajdonosai, és még inkább a meghatározó irányítói világszerte egyre inkább más országok vagy akár más fỏldrészek polgárai vagy gazdasági társaságai (Árva-Diczházi 1998, 78).

Ez a folyamat azonban inkább egyirányú utcának tekinthető, ugyanis a fejlett országokból kiinduló mủködőtőke-kivitel több mint 90\%-a az Egyesült Államokból, Japánból, Nagy-Britanniából és Franciaországból érkezik, A nemzetközi tulajdonosi integráció koncentráltsága miatt tehát inkább globális dominanciának nevezhet- 
jük ezt a folyamatot, és ez az ideológiák és kultúrák terén is alapvetỏ minöségi változást vont maga után. A világ kultúra- és ideológiafogyasztását egyre inkább a fejlett országokból származó gazdasági társaságok ellenőrzik, ami egyre nagyobb uniformizálódást eredményez az értékrendszer, a fogyasztás, a kultúra terén. Kulturális hálózatukkal pedig hatékonyan befolyásolják a közvéleményt, s elfogadtatják azzal a nemzetgazdaságok mind nagyobb hányadának külföldi tulajdonosok által történő ellenörzését is. A tényleges gazdasági és kulturális globalizálódás elömozdítása (vagyis a régiók és országok kapcsolatainak sokoldalú erősítése) összefér az egyoldalú globális dominanciával való szembenállással. Azt a kérdést, hogy a globalizálódás az emberiség fényes jövője vagy zsákutca, még nem lehet megválaszolni. A nyerỏ stratégia hazánk számára egy olyan ésszerü alkalmazkodás lehet, melylyel igyekszik a globalizáció előnyeit kihasználni, ugyanakkor a lehető legtöbbet megőrizni saját európai és magyar identitásából. A rendszerváltással bekövetkezett fordulat egyik alapvető eleme az ország megnyitása a külföldi müködő töke nagyarányú beáramlása elôtt a kilencvenes évek elejétől, melynek hatására az e tőkével müködő cégek száma az évtized közepéig rohamosan nőtt (1996-ig 2000 fölé), utána a növekedés már mérsékeltebb volt. A külföldi töke aránya a vállalatok öszszes jegyzett tökéjében 1998-ban 37,6\%-ot, e vállalatok exportjának aránya az ország exportjában $79 \%$-ot ért el. A külföldi tőke beáramlásának egyik formája a privatizáció volt, de megkülönböztetett jelentőségük van a zöldmezős beruházásoknak is (Schweitzer 2002).

A külföldi beruházókat Magyarországon elsősorban a viszonylag képzett, de mégis relatíve olcsó munkaerö, a korszerü telekommunikációs és pénzügyi infrastruktúra, a viszonylag képzett menedzserek, a korszerủ technológiák gyors elsajátítására való készség vonzották. A magyarországi privatizáció következtében egy korábban döntő részt zárt piacon részesedést tudtak szerezni, nyitni tudtak FÁK-beli és egyéb közép-kelet-európai piacok felé. Ugyanakkor a külföldi beruházók nehezítő körülményként említik meg a nem kielégítő jogi garanciákat, a gazdasági szabályozás bizonytalanságait, a fejletlen közlekedési rendszert, valamint privatizált - egykori állami - vállalatok esetében a túlfoglalkoztatást, az elavult információs szervezetet, a rejtett környezeti károkat, a szervezetlenséget, az alacsony hatékonyságot stb.

Külföldi kontroll alatt van az jpar mintegy kétharmada, a távközlés több mint 90\%-a, az energiatermelés- és elosztás közel $60 \%$-a, a pénzintézeti szektor

70\%-a, a kereskedelem fele (Árva-Diczházi 1998, 243).

Győr a külföldi befektetések egyik célterülete. A fentebb említett előnyök mellett az ide történő müködőtőke-beruházásokat motiválhatta, hogy Győr korábban is erös gazdasággal és nyugat-európai kapcsolatokkal rendelkezett, elsők között indult meg itt a privatizációs folyamat, közel van Nyugat-Európához és három európai fővároshoz (Bécs, Pozsony, Budapest), viszonylag jó a közlekedési lehetőség. Budapest és Pest megye után itt a legnagyobb a külföldi tulajdon aránya. A városban és vonzáskörzetében 2002 januárjában 339 vegyes, ill. külföldi cég müködött. A külföldi befektetők közül (melyek 41 országból érkeztek) a legnagyobb az osztrákok részesedése a jegyzett tökében (52\%), őket követik a németek és az angolok (12-12\%), a 
hollandok, a franciák stb. (Páll 2002). A nemzetközi vállalatok más-más kultúra hatását terjesztik.

A Györött dolgozó magyar és más nemzetiségü menedzserek az interkulturális környezet előnyeit és nehézségeit napi munkájuk során is átélik.

„A nemzetközivé válás - az idegen nyelv ismerete kérdésén túl - felvet egy, a menedzserekkel szemben támasztott további elvárást: az arra való felkészuiltség igényét, hogy képesek legyenek egy más nemzeti kultúra közegében, vagy több kultúrájú, multikulturális vállalati keretek között adekvát módon irányítani, és a szoft tényezök szinergiára vezetö kiaknázását megtalálni." (Borgulya 2002, 177)

A nyitott gazdaság által megkívánt újszerü kommunikációra és interkulturális érintkezésre nem csupán a menedzsmentnek, hanem az ilyen vállalatoknál dolgozó alkalmazottaknak is szükségük van.

\section{A témaválasztás oka}

A fentebb leírt nemzetközi gazdasági integrációs folyamatok következtében a magyar munkavállalók is egyre gyakrabban kerülnek munkakapcsolatba külföldiekkel, más kultúrák képviselöivel. Az eredményes együttműködésnek többek között az is elöfeltétele, hogy az üzleti partnerek sikeresen tudják kezelni a kultúrák eltéréséböl adódó különbözőségeket. Ezért a hazai oktatásban is egyre inkább helyet kell kapnia az interkulturális feladatokra való felkészítésnek.

\section{A kutatási minta}

A vizsgált vállalat az 1993-ban zöldmezös beruházásként létrejött, német-osztrák tulajdonú VAW Alumíniumtechnika Kft, amely a vizsgálat idöpontjában - 2002 márciusában - kb. 550 föt foglalkoztatott, közülük 54 menedzser és adminisztratív munkakörben dolgozó személy megkeresése és megkérdezése történt meg kérdöív segítségével, s mindannyiuktól értékelhető válaszok érkeztek vissza.

\section{A kutatás célja}

Az említett időpontban már tudott volt a vállalat minden dolgozója számára, hogy egy norvég vállalat, a Norsk Hydro megvásárolta a VAW-t. Ekkor a vállalat vezetésével idöszerünek tartottunk egy felmérést az idegen nyelvek és kultúrák témakörében. Átfogó képet kívántunk kapni a vállalat e területén dolgozók nyelvtudásáról, a nyelvek presztízséröl, a fejlesztendő területekről, a külföldi érdekeltségnek a munka világára és a civil szférára gyakorolt hatásáról, a külföldiekkel való munkakapcsolat tapasztalatairól, az interkulturális kooperációra való felkészültségröl, a tulajdonosváltástól várt változásokról. 


\section{A kutatás módszere}

A kutatás súlypontja empirikus felmérés: információgyűjtés kérdőív segítségével. Ennek összeállításakor figyelembe vettük a vállalatvezetés célját, a kutatás eredményének várható hasznosítását a nyelvoktatás és a felsőoktatás számára. Igénybe vettük két, hasonló jellegü munka kérdőíveit és tapasztalatait: egyrészt a Pécsi Tudományegyetemen 1996-ban Pécsett és Baranyában, másrészt András István által 1999-ben a Dunaferr Csoportnál végzett kutatás során használt kérdőíveket. Mindezeket figyelembe véve a kérdéseket négy nagyobb téma köré csoportosítottuk:

1) nyelvtudás, nyelvhasználat;

2) interkulturális tapasztalatok, felkészültség;

3) motiváció;

4) a külföldi tulajdonos kultúrája által közvetített hatás.

\section{Nyelvtudás, nyelvhasználat}

A kérdőív első része felmérte a megkérdezettek interkulturális együttmüködésre való nyelvi felkészültségét. 74,5\%-uk szerint a külföldi tulajdonosi érdekeltség szükségessé tette a célnyelv ismeretét, $21,8 \%$-uk szerint csak kis mértékben növelte ezt az igényt. Napi munkájukhoz $87 \%$-uknak van szüksége idegen nyelv tudására (nyilvánvaló tehát, hogy még a külföldi tulajdonosi érdekeltségủ cégeknél sem minden alkalmazottnak kell idegen nyelven beszélnie). Nyelvtudásuk szintjét nem mindegyikük tartja tárgyalóképesnek: 41,8\%-uk egy nyelven, 10,9\%-uk két, 3,6\%-uk három nyelven tartja magát tárgyalóképesnek az anyanyelvén kívül. Közülük a németet használta leginkább munkanyelvként $68 \%$, az angolt $14,5 \%$, mindkét említett nyelvet $14,5 \%$.

Az osztrák-német tulajdonú cég felvásárlása a norvég befektető által növeli az angolnak mint munkanyelvnek a jelentőségét. A vállalat sok pénzt áldoz a nyelvtanulásra (jelenleg föleg az angolra), a tanfolyamköltségek átvállalásával, munkaidőkedvezménnyel támogatja azt. A külföldi jelenlét tehát megnövekedett nyelvtudási igényt hoz magával, aminek kielégítése érdekében szervezett vállalati kurzusok növelik a nyelvtanulás lehetőségét. A nyelvtudás a vállalat számára stratégiai kérdés. Egyes számítások szerint ugyanis a kommunikációs zavarok nagyobb pénzügyi kárt okoznak, mint a technológiaiak. A „Mely nyelv ismeretére lenne még/inkább szüksége?" kérdésre adott válaszok is az angol presztízsének és szükségességének erőteljes növekedését mutatják: a németet $12,7 \%$, az angolt $65,4 \%$, a kettőt együtt $9 \%$-uk tartja szükségesnek. Tanúi lehetünk az angol nyelv uralkodó helyzetủvé válásának, mely a vizsgált vállalatnál a munkanyelv váltásának és a globalizációnak egyaránt következménye. A globalizáció következtében az angol nyelv tudása elengedhetetlenné vált az egész világon.

„Szinte valamennyi szféra, az üzletitől a tudományosig, az informatikától a közlekedésig közös érintkezési nyelvvé tette... Ugyanakkor megfordítva is 
igaz: a globalizáció egyik fỏ eszköze az angol, illetve másként fogalmazva:

az angol egyik előfeltétele a nemzetközivé válásnak." (Hidasi 2002,9)

A nyelvek presztízsét mutatja annak a felmérése, hogy a válaszadók mely nyelv/nyelvek elsajátítását tartják/tartanák fontosnak gyermekeik számára. Megneveztünk kilenc nyelvet (angol, francia, japán, kínai, latin, német, olasz, orosz, spanyol), s egyéb kategóriával lehetőséget adunk egyéni igények jelzésére is. Az 1-töl 9-ig rangsorolás során legfontosabbnak tartott nyelv kapott egyes sorszámot. Így a nyelv helyezésének összpontszáma, és a nyelvet említők hányadosa olyan arányszámot ad, amely akkor kedvezö, ha értéke 1-hez közelít (pl. a spanyolt hárman említik 2 . helyen $=6$, tízen 3 . helyen=30, tizennégyen 4 . helyen=56, tizenegyen 5 . helyen $=55$, kilencen 6 . helyen $=54$, egy válaszoló pedig 7 . helyen $=7$. Így $208 / 48=4,3$, azaz a spanyolt a megkérdezettek a 4 . és 5 . hely közé rangsorolták, inkább negyediknek, mint ötödiknek) ( $I$. ábra).

\section{1. ÁBRA}

Gyermekének mely nyelv(ek) elsajátítását tartja a legfontosabbnak?

(Which Language(s) Do You Think the Most Important for Your Children to Learn?)

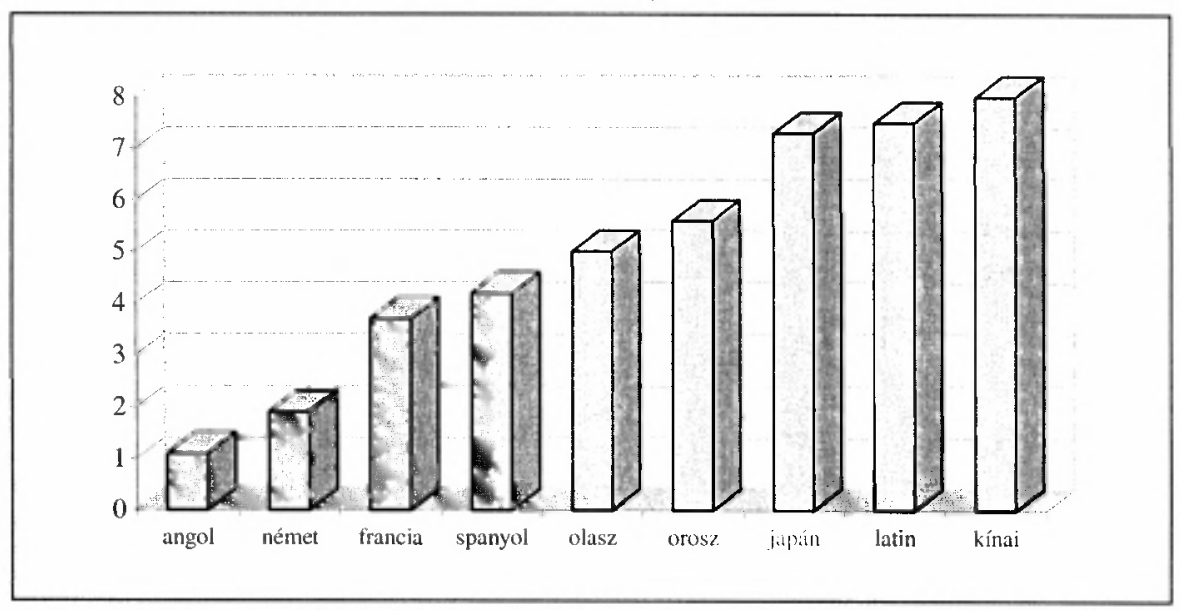

Forrás: Kérdōivek 2002.

Érdemes elgondolkodni azon, hogy az egyéb kategóriában sem történik említés egyetlen szomszéd ország nyelvéről sem (kivéve a németet), tehát a megkérdezettek nem tartják szükségesnek, hogy gyermekeik szlovák, román, horvát stb. nyelveket beszéljenek. Ugyanakkor az EU nyelvpolitikája szerinti ideális europolgár három nyelvet beszél az anyanyelvén kívül, s ezek közül az egyik egy szomszédos nyelv. A szomszédos országok nyelveinek népszerüsítése lehet a magyar nyelvpolitika egyik feladata.

A vállalat minden területén fókuszba került a nyelvtudás. A válaszolók szerint leginkább a müszaki területen szükséges (33\%), de a gazdasági $(19,2 \%)$, a menedzsment $(17,4 \%)$, a kereskedelmi $(16,5 \%)$, az adminisztratív $(13,7 \%)$ munka 
eredményes végzése is szükségessé teszi azt. Eszerint tehát a müszaki szakemberek szakmai nyelvtudására mutatkozik a legnagyobb igény, de figyelemre méltó az is, hogy az adminisztratív munkakörben foglalkoztatottakkal szembeni idegennyelvtudás iránti elvárás alig marad el a kereskedelmi és menedzser feladatokat ellátókétól.

Szintén tanulságos a nyelvtudás szerzésének útjait vizsgálni. A válaszolók többsége a nyelvtudáshoz több forrásból jutott hozzá (iskola, tanfolyam, célország, ill. ezek variációi) (2.ábra).

\section{2. ÁBRA \\ A nyelvtudás szerzésének útjai \\ (The Origin of the Language Knowledge)}

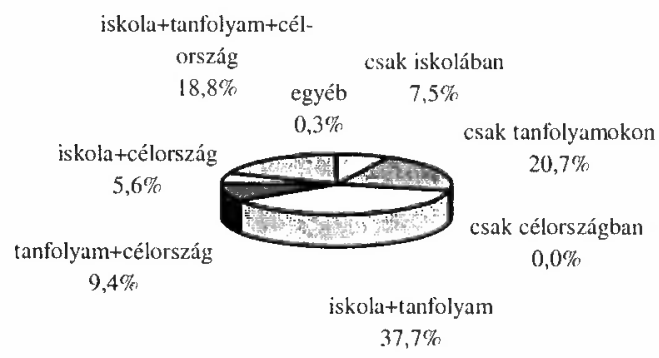

Forrás: Kérdöívek 2002.

Ahogy a fenti ábrán látható, legnagyobb arányban az iskola és tanfolyam együttesét említik, magas a „csak tanfolyam” kategória aránya is. A csak iskolában szerzett nyelvtudás aránya 7,5\%, legritkább az iskola és célország együttes említése. Egyéb módként említésre került a magántanárral, ill. autodidakta úton való tanulás. Meglepö, hogy az összes említések számát nézve a tanfolyamok jelentősége $(45,6 \%)$ jóval meghaladja az iskolákét $(36,5 \%)$ és a célországét $(33,8 \%)$ a nyelvtudás szerzése szempontjából. Fontos feladat tehát az iskolai nyelvoktatás hatékonyságának fejlesztése, valamint a külföldi - nyelvtanulással összekapcsolható - utazások számának növelése.

A kommunikatív nyelvtudás szükségességének újabb bizonyítéka az idegen nyelvek használata során leginkább nehézséget okozó tényezők vizsgálata. Az 54 válaszadó személy a gyakorlás lehetőségének hiányában (27\%), a szókincs hiányosságában $(17,8 \%)$, a nyelvtani szabályokban $(16,6 \%)$, a dialektusokban (10,7\%) és a beszéd, a szóbeli kommunikáció nehézségében $(9,5 \%)$ látja a legnagyobb kihívást. A szakmai nyelvet 9,5\%, az írást 7,1\%-ban említik nehézségként. A hazai külföldi, ill. vegyes tulajdonú vállalatok jelentős szerepet töltenek/tölthetnek be a nyelvtanulás támogatásával (külföldi utazások, támogatott nyelvtanfolyamok). 


\section{Interkulturális tapasztalatok, felkészültség}

A kérdőív második részében annak vizsgálatára vállalkoztunk, hogy felmérjük, hogyan tudnak felkészülni a vizsgált külföldi vállalat magyar alkalmazottai a kultúrák különbözőségéböl eredő problémákra; milyen lehetőségeik voltak/vannak multikulturális jártasság szerzésére. A külföldi tulajdonban levő vállalatok ugyanis gyakran közvetítik a tulajdonos kultúráját, így ezek a kultúrák találkozásának jellegzetes helyszínei. A különbözö kultúrák érintkezési, viselkedési, tárgyalási szokásaiban pedig nagy különbségek vannak, így könnyen támadhatnak félreértések, téves értelmezések. Hogyan lehet eredményesen kommunikálni? Mit lehet tenni, hogy a zavarokat megelőzzük?

A tanulás, a tudatosítás, a felkészuilés és a tapasztalás kialakít egyfajta gondolkodásmódot, nyitottságot, rugalmasságot, empátiát, fejleszti az ítélőképességet. A vizsgált vállalat megkérdezett alkalmazottainak $67,2 \%$-a (ezen belül $10 \%$-uk rendszeresen, 54\% többször, 5\% háromszor, 13,5\% kétszer, 13,5\% egyszer) vett rész külföldi továbbképzésen (3. ábra).

\section{3. ÁBRA}

Hány alkalommal vett részt külföldi továbbképzésen?

(How Many Times Have You Participated in Foreign Training?)

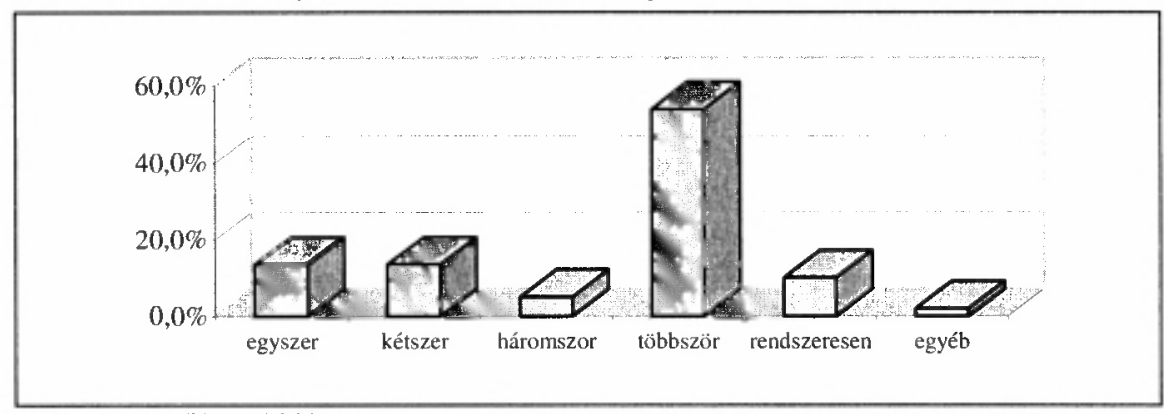

Forrás: Kérdőívek 2002.

\section{4. ÁBRA}

Milyen hosszú ideig vett részt külföldi továbbképzésen?

(How Long Have You Been in Foreign Training?)

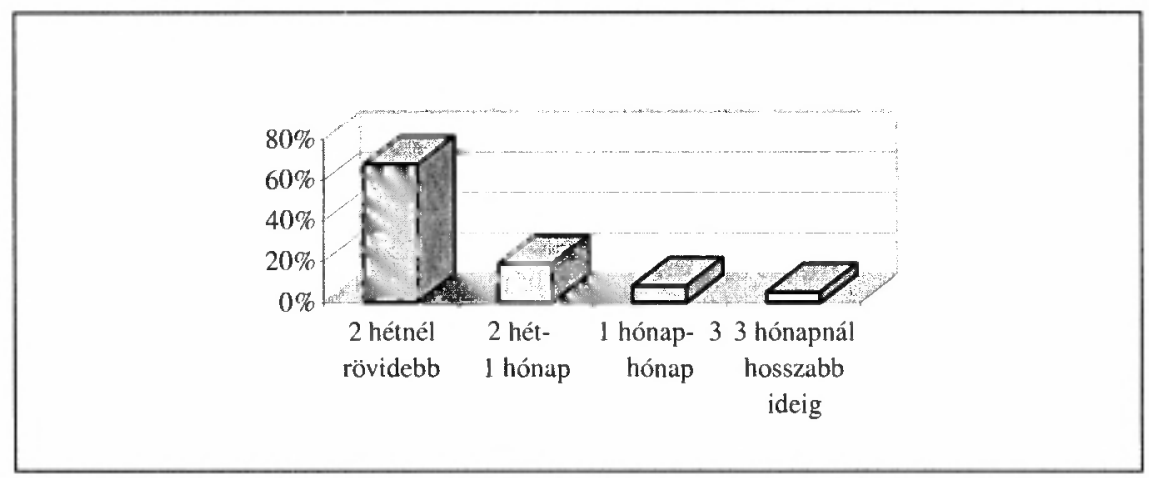

Forrás: Kérdőívek 2002. 
A külföldön tartózkodás azonban többnyire két hétnél rövidebb idö volt (67,5\%), csupán 5,2\%-uknál volt három hónapnál hosszabb (4. ábra).

Az elöző adatokból levonható az a tapasztalat, hogy csak az interkulturális ismeretekkel való felvértezettség nyújthat reményt a „miscommunicatio” (gyüjtőfogalom: félreértés, félremagyarázás, meg nem értés, meg nem értettség) elkerülésére. A megkérdezettek 33\%-a átélt már ugyanis a közös munka során olyan konfliktust/félreértést/mulatságos helyzetet, amely kifejezetten a kultúrák különbözöségére volt visszavezethetö. Persze már abban a tekintetben is óriási különbségek vannak a kultúrák között, hogy mit tekintenek konfliktusnak (e témában legismertebb Geert Hofstede, holland kutató által leírt négy kulturális dimenzió, illetve Edward T. Hall, amerikai antropológus kontextussal kapcsolatos dimenziója). A konfliktusok forrása lehet kognitiv alapú általánosítás (sztereotípia, mely pozitív és negatív egyaránt lehet) és affektív-érzelmi alapú elö́télet is, mely mindig negatív. Mindkettő oka kereshető az egyénben és a társadalomban is. Az egyén gondolkodását elöfeltevések, elvárások egész sora uralja, melyek éppúgy beépülnek az egyénbe, mint a közösség által közvetített minden más tudás. Olyan sematizáló, nem objektív, kognitív folyamat eredményeként jönnek létre, amely során parciális tapasztalatokat általánosítunk, csoport kategóriákat, illetve akkulturációs folyamatokat veszünk át direkt vagy indirekt módon (Bergler-Six 1972). A pozitív sztereotípia (pl. az angolok udvariasak, az olaszok jól énekelnek, a németek pontosak) megkönnyítheti az alkalmazkodást, meggyorsíthatja a döntést. A negatív sztereotípia, ill. az elöítélet azonban gátolhatja az eredményes kommunikációt. Az interkulturális sztereotípia vizsgálata Európában 2002-ben különös aktualitással bír. A felerősödött integrációs törekvések és politikai változások katalizátorként hatottak a nemzeti identitástudat erősödésére. Így az európai integráció nehezebb része nem a pénzügyi vagy jogi rendszerek különbözőségében vagy az államapparátus országonként eltérő szerveződésében keresendő, hanem a kulturális sokszínüségben, értékrendbeli eltérésben és az ezekböl adódó kommunikációs nehézségekben.

A vizsgált győri vállalatnál a megkérdezettek $16,2 \%$-a dolgozott is külföldön három hónapnál hosszabb ideig: német, osztrák, holland kollégákkal. A szerzett tapasztalatok vegyesek: 33\% nyilatkozott úgy, hogy szeret velük dolgozni; szintén $33 \%$ úgy, hogy mindegy, milyen kultúrabelivel dolgozik; $22 \%$ szeret velük dolgozni, de megítélésük szerint vannak zavaró momentumok. Csupán egy válaszadó írta, hogy nem szeret külföldiekkel dolgozni, s egy sem jelölte meg azt a választ, hogy jobban szeret saját kultúrájához tartozókkal dolgozni. Tehát megállapítható, hogy minél nagyobb valakinek az interkulturális tapasztalata, annál türelmesebb az esetleges kommunikációs nehézségek iránt, annál zavartalanabb a kommunikáció. Ez pedig záloga az üzleti sikernek és a politikai békességnek egyaránt.

\section{Motiváció}

A kérdőívben szereplö kérdések harmadik csoportja a motivációval kapcsolatos. Arra kerestük a választ, hogy mi ösztönzi a vállalat megkérdezett dolgozóit a munkában és a nyelvtanulásban. A kérdéscsoport első felében arra kértük öket, rangso- 
rolják az alábbi öt motiváló tényezőt ötjegyủ skálán (a legjelentösebb kapjon ötöt, a legkevésbé jelentős egyet): pénz, magasabb fizetés, jutalom; nyilvános elismerés; elöléptetés, státus; a feladatban rejlö kihívás, bizonyítani akarás; az önmegvalósítás lehetősége (5. ábra).

\section{5. ÁBRA}

Mi motiválja Ön szerint leginkább az ön kultúrájához tartozókat a munkában? (What Do You Think the Most Important Insentive of People of Your Own Culture in Working?)

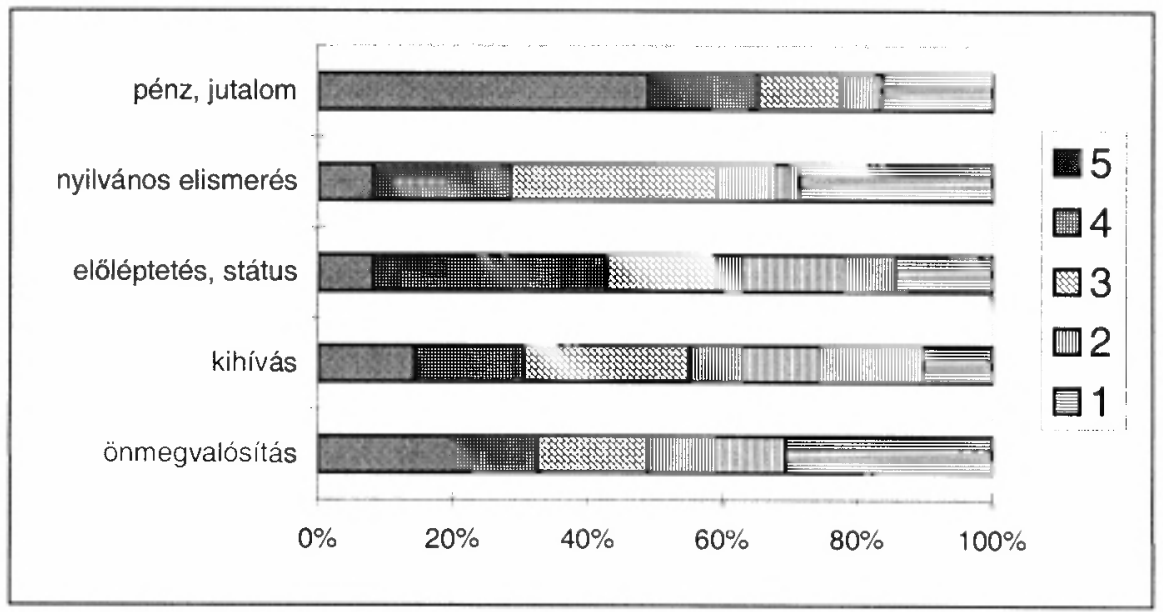

Forrás: Kérdöívek 2002.

A kérdés tehát nem csupán a megkérdezettre irányult, hanem általánosítva a saját kultúrájához tartozókra. A kialakult rangsorban a legfontosabbnak tartott motiváló tényező a pénz $(3,7)$, amely az emberek többsége számára stratégiai jelentőségü: munkájuk értékét és mások általi értékelését tükrözi. Hiánya elégedetlenséget nagyobb erővel tud kiváltani, mint megléte elégedettséget. Ha elég sok van belőle, elveszíti motiváló erejét. Mivel a megkérdezettek fele a legfontosabb motivátornak tartja a pénzt, így ezt az elégedetlenség egyfajta jelének tekinthetjük a közvélemény szerint jól fizető cég alkalmazottai körében. A megbecsülési szükségletek fontosságát jelzi az elöléptetés, státus második helyre kerülése $(2,9)$. A harmadik fontosnak tartott motiváló tényezö, a bizonyítani akarás $(2,8)$, illetve az önmegvalósítás lehetősége $(2,7)$ az a munkamotivációs ütőér, amely a 21 . században rendkívüli fontosságúvá vált. A nyilvános elismerést közel ilyen fontosnak tartják, hiszen kevés dolog motivál jobban, mint a dicséret. Az elismerés utáni vágy univerzális jelenség.

A kérdéscsoport második fele a nyelvtanulás motivációira fókuszál. Egyesek azért tanulnak nyelveket, hogy nemzetközibbé váljanak, mások - épp ellenkezőleg azért, hogy nemzeti azonosságukat megőrizzék. A nyelvtanulási motivációk tehát különfélék lehetnek:

- Ideológiai - a domináns hatalom nyelvének ráerỏltetése a kiszolgáltatott helyzetben levő népcsoportra; 
- Önazonosság, identitástudat erősítése - különösen a kisebbségek esetében jellemzö (pl. a wales-i nyelv reneszánsza Nagy-Britanniában);

- A nyelvi és kulturális jogok megörzésének szándéka - pl. a québec-i franciák érdekében rendelet írja elö, hogy a francia nyelvű feliratoknak kétszer akkoráknak kell lenniük, mint az angol nyelvüeknek;

- A sokszínủség megőrzésének és biztosításának a szándéka (pl. az EU nyelvpolitikai irányzata);

- Formai követelményeknek, szakmai elvárásoknak való megfelelés kényszere (pl. bizonyos címek, diplomák, pozíciók, kvalifikációk elnyerése);

- Nemzetközi érintkezés iránti igény - idegen kultúrák elsajátításának és sajátunk megmutatásának igénye (Hidasi 2002, 10).

Mi ösztönzi a vizsgált vállalatnál megkérdezetteket arra, hogy idegen nyelveket sajátítsanak el? A válaszokból az derül ki, hogy a felsorolt öt motiváló tényező közül a nyelvtanulás motiváltságában a munkahelyi lehetöséget tartja a többség a legfontosabbnak $(35,7 \%)$. A kihívás $(21,4 \%)$, a környezet motiváló ereje, illetve a munkahelyi kényszer $(15,4-15,4 \%)$ mellett jelentős azok aránya is $(11,9 \%)$, akiket a kultúra iránti érdeklődés mozgat. A szakmai elvárásoknak való megfelelés és a nemzetközi érintkezés iránti igény tehát a legfőbb hajtóerök a nyelvtanulásban. Érdekes tapasztalat egyrészt, hogy amíg a munkában a pénz motivál a legjobban, a nyelvtanulásban ez szempontként nem jelent meg; másrészt szerencsésen kapcsolódik össze a vállalati és az egyéni érdek: a munkahely által felkínált lehetöség (a támogatott nyelvtanulás), illetve a vállalat nyelvtudás iránti igénye.

\section{A külföldi tulajdonos kultúrája által közvetített hatás}

A kérdések negyedik csoportja arra vonatkozott, milyen új elvárásoknak kell megfelelniük az alkalmazottaknak a külföldi tulajdonú cégeknél; a külföldi tulajdonos által képviselt kultúra milyen értékeket közvetít, mit eredményez (a viszonyítás alapja egyrészt az elöző cégeknél szerzett tapasztalat lehet, hiszen a VAW zöldmezős beruházásként jött létre, illetve az itt szerzett multikulturális tapasztalat). A vizsgált cégnél bekövetkező tulajdonosváltástól várnak-e változást a megkérdezettek, $\mathrm{s}$ ha igen, milyen jellegüt?

Az első kérdésre - „A külföldi tulajdonos az Ön cégénél milyen interkulturális hatást közvetített?" - huszonhárom válaszlehetőséget soroltunk fel (András 1999, 65), amelyek közül a megkérdezettek tetszés szerinti mennyiségben választhatták ki a szerintük legjellemzőbbeket a munka világából és a civil szférából (6. ábra).

A civil szférában bekövetkezỏ legjelentősebb hatásként a felsorolt válaszlehetöségek közül (szokások átvétele; kapitalista szemléletmód; kulturális látókör bővülése; az ítélóképesség alakítása; igényesség; a gondolkodásmód változása) a gondolkodásmód változását jelölték meg a válaszadók. A munka világában bekövetkező operatív hatások közül (kötetlen munkaidő; szokások átvétele; a tulajdonos szokásainak megfelelő viselkedés; normák átvétele; fegyelmezett, feszített munkatempó; technikák, módszerek megismerése, átvétele, alkalmazása) legtöbben a technikák, 
módszerek átvételét, illetve a fegyelmezett, feszített munkatempót érzékelték változásként. A munka világában bekövetkezỏ stratégiai hatások közül (központba kerül a PR-tevékenység; nemzetközi összehasonlítás; a cég iránti elkötelezettség el várása; szakmai látókör bővülése; fokozott környezetvédelem; igényesség; fokozott egészség- és munkavédelem; a cég igényes külsö/belsö megjelenése; fokozott elvárások teljesítése; profitszemlélet felerósödése) a profitszemlélet felerősödése mellett a fokozott elvárások teljesítése változott meg markánsan a megkérdezettek véleménye szerint. Megfigyelhetjük tehát, hogy a vállalat vezetésének nem csupán a technikák átvételét, hanem a sokkal nehezebben, időigényesebben formálható gondolkodásmód, fegyelmezettség, igényesség változását is sikerült elérnie az emberi eröforrás-menedzselés új módszereivel.

\section{6. ÁBRA}

A külföldi tulajdon az Ön cégénél milyen interkulturális hatást közvetített? (What Kind of Intercultural Effects Were Transmitted by Foreign Capital?)

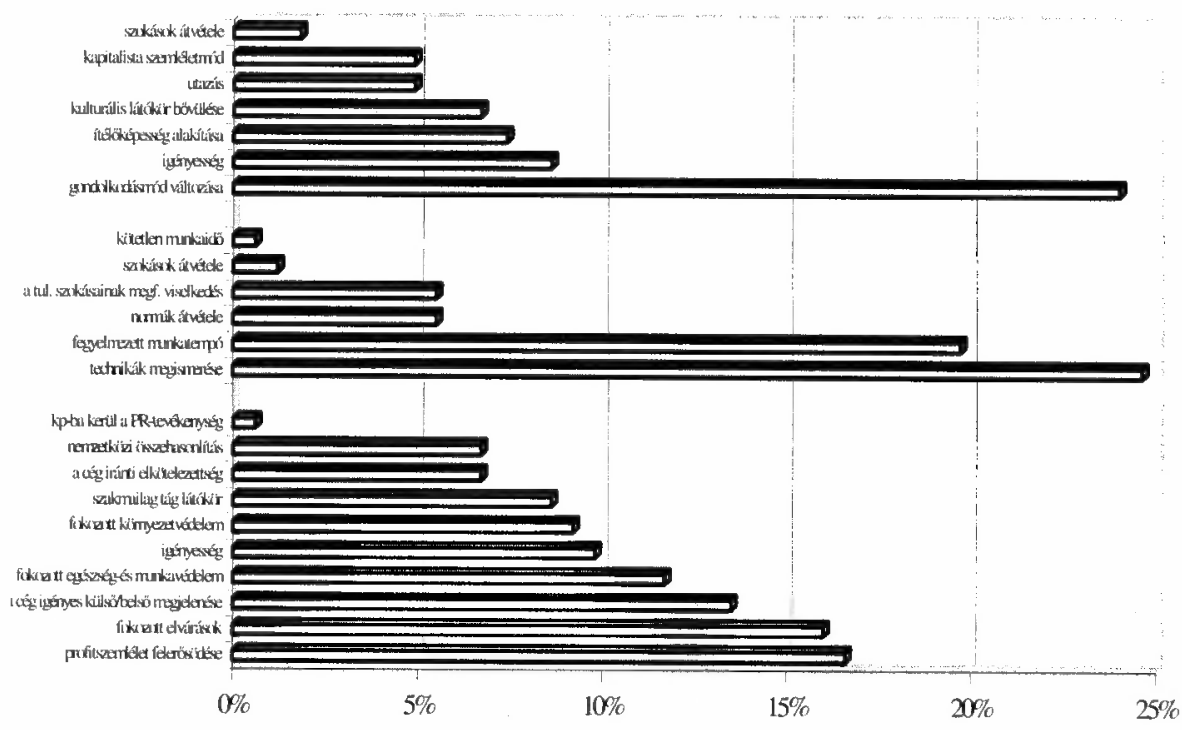

Forrás: Kérdőívek 2002.

A kérdéscsoport második fele a vizsgált cégnél bekövetkezö jelentős, tervezett változással (tulajdonosváltás: német-osztrákról norvégra, hivatalos munkanyelv váltása németröl angolra) kapcsolatos elvárásokra kérdez rá. Minden változás megtervezése és bevezetése konfliktusokat hordoz magában. A változást célzó erỏfeszítések gyakran ellenállásba ütköznek, melynek oka lehet egyéni és szervezeti félelem az újtól, az ismeretlentől; ragaszkodás a szokásokhoz; félreértés és bizalomhiány, illetve a hatalmi pozíció féltése. A változással szembeni ellenállást - felmérve és megfelelő módszereket, stratégiát alkalmazva - le lehet győzni. A változások 
mibenlétére tizenhárom válaszlehetöséget soroltunk fel, melyeket 1,2 vagy 3 számmal lehetett értékelni: 1 , ha várhatóan rosszabb lesz a helyzet; 2 , ha nem várható érzékelhető változás; 3 , ha egyértelmü javulás várható (7. ábra).

\section{7. ÁBRA}

Az Ön cégénél bekövetkezö tulajdonosváltástól Ön milyen változásokat vár? (What Kind of Changes Do You Expect from the Ownership Change of Your Company?)

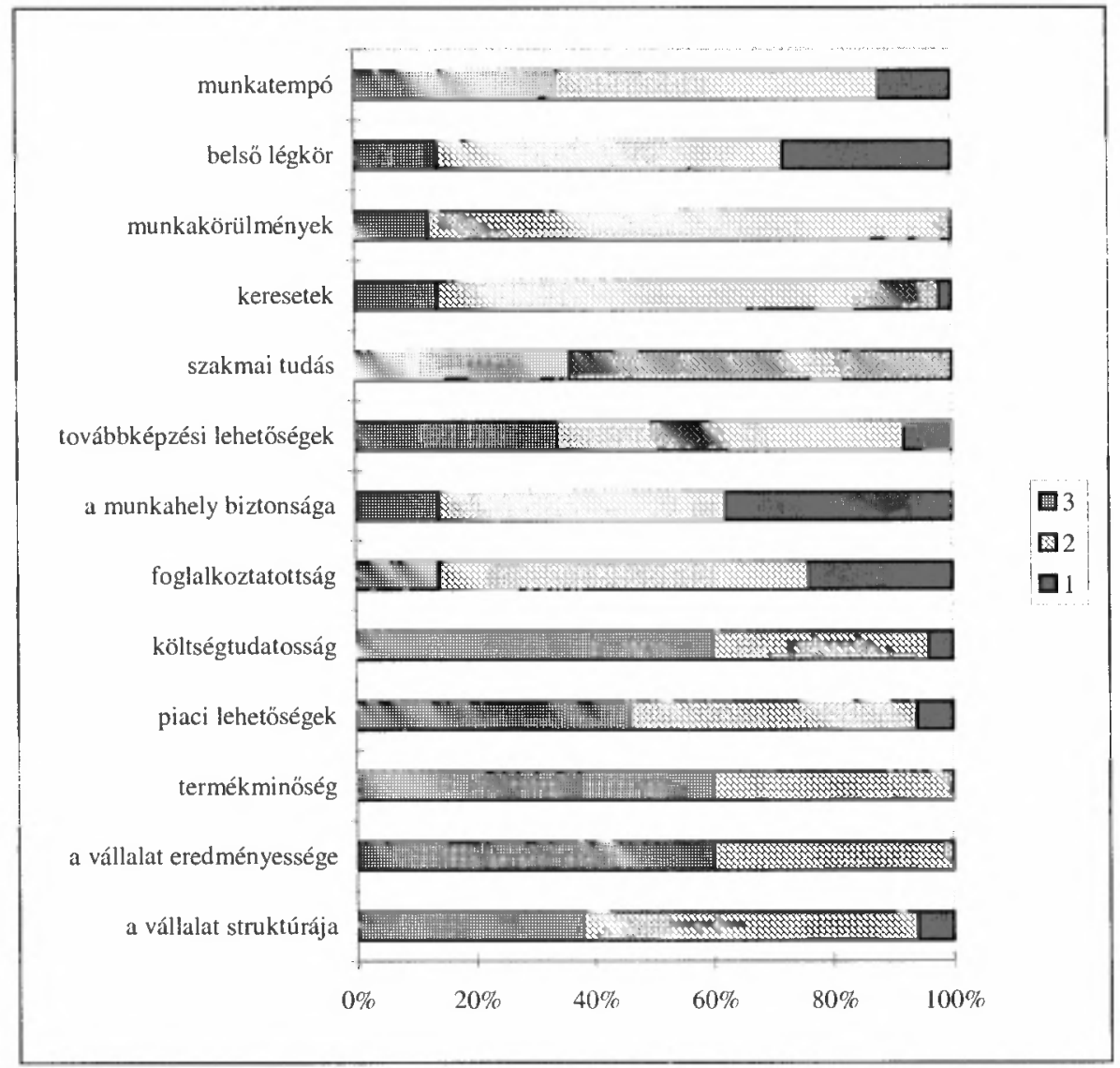

Forrás: Kérdőívek 2002.

Az ábra alapján látható, hogy a válaszadók egy része rosszabb helyzetre számít a munkahely biztonsága, a foglalkoztatottság és a belső légkör terén. Egyértelmü javulást várnak a vállalat eredményessége, a termékminöség, a piaci lehetőségek, a költségtudatosság, a továbbképzési lehetőségek és a szakmai tudás szempontjából. 


\section{Összegzés, következtetések}

1) A külföldi tulajdonú vállalatok a magyarországi tulajdonszerzéssel anyagilag is érdekeltté válnak az ország külső és belső biztonságában. A külföldi vállalatok jelenléte stabilizációs szerepet tölt be, így a nemzetbiztonsági stratégiának is egyik elemét jelentik.

2) Bár több felmérés is azt igazolja, hogy a külföldi mủködötőke-beruházások, illetve a magyar privatizáció sajátos, mindenekelőtt külföldi tőkebevonásra építỏ útja egyre kisebb támogatást élvez a közvéleményben, ugyanakkor a dunántúli városokban - így pl. a Győrött - élők sokkal pozitívabban viszonyulnak a nyugati befektetőkhöz, megtapasztalva a külföldi beruházások foglalkoztatási és jövedelemszerzési elönyeit.

3) A magyar menedzsereket és alkalmazottakat a multikulturális gyakorlat, tapasztalat, illetve nyelvtudás versenyképes munkaerővé teszi az EUországokban, illetve a világpiacon. 2004-re az EU tíz újabb államnak ajánlotta fel a csatlakozást, mely lehetóség és kihívás is egyben. A külföldi tulajdonú hazai vállalatok az interkulturális együttmüködés „felkészítő mủhelyei”. Folyamatos vizsgálatuk motiválhatja az újabb kutatásokat és a felsóoktatás gyakorlat-központúbb átalakítását.

4) A vizsgált külfoòldi tulajdonú cégnél a megkérdezettek úgy ítélték meg, hogy átalakult, bővült kulturális látószögük, megnövekedett a szakmai utazások lehetôsége. A külföldi jelenlét - amely megnövekedett nyelvtudásigényt hoz magával - motiválja a nyelvtanulást, és az igény kielégítése érdekében szervezett vállalati kurzusok növelik a nyelvtanulás lehetőségét.

5) Szükséges az iskolai nyelvoktatás hatékonyságának növelése, valamint a szomszédos országok nyelveinek népszerüsítése.

6) Az elöítéletek tanulással csökkenthetỏk. Az oktatásnak jó esélyei vannak az interkulturális kommunikáció előítéletekbỏl fakadó zavarainak leküzdésére.

\section{Irodalom}

András I. (1999) Termelés, kultúra, nyelv. Dunatáj Kiadó Kft., Dunaújváros.

Árva L.-Diczházi B. (1998) Globalizáció és kiilfóldi tőkeberuházások Magyarországon. Kairosz Kiadó, Budapest.

Bergler, R.-Six, B. (1972) Stereotype und Vorurteile. - Irle, M. (Hrsg.) Handbuch der Psychologie in zwölf Banden. Bd. 7/2. Socialpsychologie. Hogrefe, Göttingen. 1371-1433. o.

Borgulya Istvánné (szerk.) (1999) A magyar menedzserek és az interkulturális feladatok '98. JPTE Közgazdaságtudományi Kar, Pécs.

Borgulya Istvánné (2002) A szoft tényezỏk az átalakuló magyar gazdaságban. -Farkas F. (szerk.) A magyar tudomány napja. Pécsi Tudományegyetem, Pécs. 172-178.o.

Hall, E.T. (1994) Kontext and Meaning.-Samovar, L.A.-Porter, R.E. (eds.) Intercultural Communication. Wadsworth Publishing, Belmont. 60-70. o.

Hidasi J. (2002) Metszéspontok: nyelvek és kultúrák. - Modern Nyelvoktatás. 2-3. 9-13. o.

Hofstede,G. (1991) Cultures and Organizations: Software of the Mind. Mc Graw-Hill, London.

Páll Gy. (2002) Tulajdonviszonyok változása a gazdasági társaságokban 1993-2000 között GyőrMoson-Sopron megyében. - Adóvilág. 3, 45-49. o.

Schweitzer I. (2002) A hazai beruházások alakulásának fơbb tendenciái az elmúlt évtizedekben és néhány tanulság. - Külgazdaság. 7-8. 4-32. o. 